\title{
Acute coronary syndrome and renal impairment: a systematic review
}

\author{
Marco Di Mauro ${ }^{1}$, Vincenzo Fiorentini ${ }^{2}$, Raffaella Mistrulli ${ }^{2}$, Francesco Antonio Veneziano ${ }^{3}$, \\ Leonardo De Luca ${ }^{4,5, *}$
}

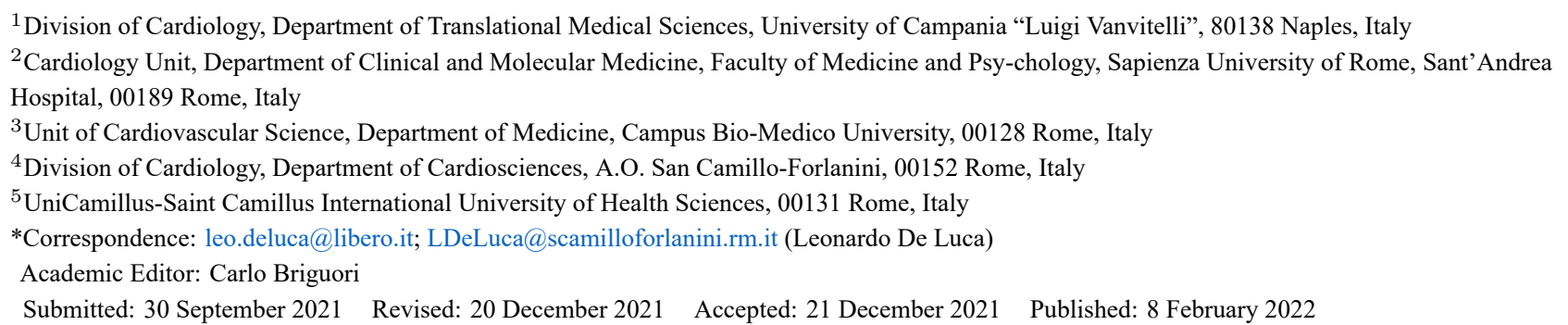

\begin{abstract}
Background: Coronary artery disease (CAD) and chronic kidney disease (CKD) may reciprocally influence each other. Patients with CAD and CKD have an increased risk of both ischemic and hemorrhagic events. Methods: In the present review, we summarize the existing literature focusing on the relationship between kidney dysfunction and acute coronary syndromes (ACS) in terms of risk factors, complications, and prognosis. We discuss also about the best evidence-based strategies to prevent deterioration of renal function in patients with CAD. Results: Patients with CKD less frequently receive an invasive management (percutaneous or surgical revascularization) and potent antithrombotic drugs. Nevertheless, recent evidence suggests they would benefit from a selective invasive management, especially in case of ACS. Conclusion: Patients with CKD and CAD represent a challenging population, more randomized controlled trials and meta-analyses are needed to better define the best therapeutic strategy during an ACS episode.
\end{abstract}

Keywords: acute coronary syndromes; chronic kidney disease; acute kidney injure; coronary artery disease; revascularization

\section{Chronic kidney disease as risk factor of acute coronary syndrome}

The prevalence of chronic kidney disease $(\mathrm{CKD})$ in the general population stands at $13 \%$ and increases to 20 $25 \%$ in patients with acute coronary syndrome (ACS) [1]. $\mathrm{CKD}$ is an independent risk factor for cardiovascular events often consisting in pauci-symptomatic clinical presentation and atypical elettrocardiogram (ECG) changes, making the diagnosis of ACS more challenging.

It has been observed that as renal function decreases, cardiovascular risk progressively increases. Indeed, patients with renal dysfunction are most likely to present an acute myocardial infarction (AMI) [2] with an even higher prevalence of ACS in dialyzed patients. Indeed, chronic inflammation, hyperhomocysteinemia and oxidative stress leading to endothelial dysfunction, coronary artery calcification, as well as the use of immunosuppressants have all been associated with accelerated atherosclerosis and coronary events [3]. Periodic exposure of blood to the dialysis membrane may also induce platelet reactivity (PR), which leads to an increased risk of ischemic events and resistance to anti-thrombotic treatment in dialyzed patients $[4,5]$.

\section{Acute kidney injury}

According to the Acute Kidney Injury (AKI) Network, $\mathrm{AKI}$ is defined as an absolute increase in serum creatinine
$(\mathrm{sCr})$ of $0.3 \mathrm{mg} / \mathrm{dL}$ or greater, or as an increase to 1.5 -fold or greater from baseline. This definition was adopted by the universal guidelines developed by the KDIGO (Kidney disease-Improving global outcome) organization and is currently the most frequently used for any cause of acute renal injury [5].

A further definition has been proposed in the context of AKI relating to contrast media used during percutaneous coronary intervention (PCI). It is based on absolute increase in $\mathrm{sCr}$ level of at least $0.5 \mathrm{mg} / \mathrm{dL}$ (44 microMol/L) within 48-72 hours after contrast exposure or as a relative increase in $\mathrm{sCr}$ of $>25 \%$ [6].

Several factors, such as parenchymal ischemia, direct and indirect tubular or endothelial damage, contribute to the development of contrast induced-AKI [7]. Contrast medium (CM) induces an increase in viscosity in the renal tubule leading to renal hypoperfusion through the constriction of the vasa recta [8]. Specifically, the CM-induced hypoxic damage afflicts both medullary and cortical regions, with a consequent reduction of estimated glomerular filtration rate (eGFR) and a concomitant tubular damage. The increase of reactive oxygen species and the reduction of nitric oxide leads to renal vasoconstriction ultimately resulting in additional tubular as well as endothelial damage. This effect varies according to the osmolarity and the viscosity of the CM, with maximum damage produced by high osmolarity iodine-based contrast agent (HOCM). Furthermore, 
HOCM influences the shape of the erythrocytes, causing difficulties in the passage inside the vasa recta with consequent hypoxia of the medullary region [8-11].

The most important risk factor associated with contrast induced-AKI is a pre-existing renal dysfunction [5]. The risk of contrast induced-AKI becomes clinically evident when the baseline $\mathrm{sCr}$ concentration is $>1.3 \mathrm{mg} / \mathrm{dL}$ $(>115 \mathrm{mmol} / \mathrm{L})$ in men and $>1.0 \mathrm{mg} / \mathrm{dL}(>88.4 \mathrm{mmol} / \mathrm{L})$ in women, equivalent to an eGFR $<60 \mathrm{~mL} / \mathrm{min} / 1.73 \mathrm{~m}^{2}$ [12]. Other risk factors for developing contrast inducedAKI include diabetes mellitus (DM), hypertension, heart failure, advanced age, volume depletion, hemodynamic instability, myeloma, use of concurrent nephrotoxic medications, and large volume or high osmolality of the CM $[13,14]$. Based on this evidence, several predictive models have been identified in order to help reducing the risk of developing contrast induced-AKI after PCI with preventive targeted therapy, guiding the decision making process, and avoiding additional renal insults [5]. Specifically, pre- and post-contrast exposure models and biomarkers were proposed for contest induced-AKI prediction [14-18].

Fundamental strategies to prevent and treat contrast induced-AKI are directed to restore circulatory volume. High osmolarity of CM and increased viscosity may be mitigated with adequate hydration to reduce the CM concentration. To date several hydration strategies have been developed. In the POSEIDON trial, a left ventricular end diastolic pressure guided fluid administration resulting in a significant reduction of contrast induced-AKI compared to usual care [15]. Another strategy is based on the use of the RenalGuard® System in which the losses due to an infusion of furosemide $(0.25 \mathrm{mg} / \mathrm{kg})$ are counterbalance by an equivalent intravenous infusion of saline solution. In the REMEDIAL II trial, the use of the RenalGuard® System led to a reduction of the incidence of contrast induced-AKI [16].

The European guidelines recommend using preprocedure infusion of isotonic solution starting 12 hours before the angiography, and continuing for at least 24 hours afterwards, in order to reduce the risk of contrast inducedAKI, especially if eGFR is $<40 \mathrm{~mL} / \mathrm{min} / 1.73 \mathrm{~m}^{2}$. Pretreatment with high dose of statin in statin-naive patients is also recommended [19-21]. Based on the correlation between high osmolarity and incidence of contrast inducedAKI, iso-osmolar CM could lead to a benefit in terms of kidney damage, however conflicting data emerge from the literature [22,23].

Although the use of adequate hydration remains the cornerstone for prevention of the development of contrast induced-AKI, great attention has been placed on trying to minimize the volume of the CM. In this regard, several strategies have been developed, including the use of automatic systems for the injection of the contrast medium, such as: ACIST CVi® (ACIST Medical Systems, Eden Prairie, MN, USA), MEDRAD ${ }^{\circledR}$ Avanta system (MEDRAD Inc.,
Warrendale, PA, USA) and the AVERT ${ }^{\mathrm{TM}}$ system, followed by the second-generation DyeVert ${ }^{\mathrm{TM}}$ systems (Osprey Medical, Minnetonka, MN, USA). In the AVERT trial, AVERT $^{\mathrm{TM}}$ system, in spite of having demonstrated a decrease in the volume of CM compared to traditional methods, failed to accomplish a reduction in the incidence of contrast induced nephropaty (CIN), suggesting that the obtained reduction in the volume of $\mathrm{CM}$ that had been obtained was not sufficient to reduce the incidence of AKI [24]. The DyeVert ${ }^{\mathrm{TM}}$ system has been recently assesed in a retrospective analysis [25] of 112 patients with ACS undergoing primary PCI: use DyeVert resulted in lower contrast media used $(130$ [120-188] mL vs. 99 [69-136] mL; $p<0.001)$ and lower incidence of contrast induced AKI (odds ratio $[\mathrm{OR}]=0.37 ; 95 \%$ confidence interval $[\mathrm{CI}] 0.14$ $0.95 ; p=0.047)$ compared to propensity score matched controls. An ongoing trial (ClinicalTrials.gov Identifier: NCT04714736) is assessing DyeVert ${ }^{\mathrm{TM}}$ system in ACS setting.

Several studies have focused their attention on PCI not guided by angiographies [26]. One of these, the MOZART trial, shows how ultrasound-guided PCI is effective in reducing the requirement of $\mathrm{CM}$. In another study a total of 31 patients with advance CKD (eGFR $<30 \mathrm{~mL} / \mathrm{min} / 1.73$ $\mathrm{m}^{2}$ ) who underwent an elective PCI with zero contrast media were analyzed. A minimal contrast coronary angiogram was first performed followed by a real time intravascular ultrasound (IVUS)-guided zero contrast PCI (no earlier after 7 days of the angiography). There were no major adverse cardiovascular events or CIN [27]. However, further trials are needed to verify the effective ability of this imaging-guided PCI strategy to reduce the incidence of CIN [28,29].

\section{Impact of chronic kidney disease in ACS patients}

Approximately $25 \%$ to $30 \%$ of all ACS patients presents at least moderately reduced renal function [30,31]. Noninvasive estimation of renal function is mandatory in every patient with confirmed or suspected ACS admitted to the hospital [32]. Reduced renal function and CKD affect every stage of diagnostic and therapeutic pathway of ACS, with an important prognostic relevance.

\section{CKD and diagnosis of ACS}

High-sensitivity cardiac troponins (hs-cTn) are the best available biomarkers for early diagnostic of ACS but in CKD patients they are chronically elevated, limiting their clinical usefulness [31,33]. In a retrospective study, 3295 patients presenting chest pain were classified in subgroups based on age, sex and renal function. AMI was diagnosed in $84 \%$ of the patients and hs-cTn levels were compared between AMI and non-AMI patients in all subgroups. Optimal cut-offs values of high-sensitivity cardiac troponin I (hscTnI) for diagnosis of AMI in CKD (eGFR $<60 \mathrm{~mL} / \mathrm{min} / 1.73 \mathrm{~m}^{2}$ ) were higher in males than females, 
and specificity of $100 \%$ was reached in all groups, except in males over 60 years old with severe eGFR reduction $(<15$ $\mathrm{mL} / \mathrm{min} / 1.73 \mathrm{~m}^{2}$ ) [34]. Despite the lower specificity of hscTn in CKD patients, a threshold of $<5 \mathrm{ng} / \mathrm{L}$ may rule out myocardial injury in this population $[32,33,35]$.

\section{Prognostic impact of CKD in ACS patients}

CKD may worsen the short and long-term prognosis of patients admitted for ACS (Fig. 1). Patients with moderate and severe CKD showed significantly increased risk of hospitalization, mortality and major bleeding episodes (Table 1, Ref. [2,30,36-42]). In the HORIZONS-AMI study, patients with CKD and ST-segment elevation myocardial infarction (STEMI) treated with PCI showed higher risk of mortality, stroke, mayor adverse cardiac events (MACE), and net adverse clinical events (NACE) and non-coronary artery bypass surgery (CABG) related bleeding at 3 years, compared with patients without CKD. Notably, the mortality rate in patients with advanced CKD (creatinine clearance [Crcl] $<30 \mathrm{~mL} / \mathrm{min}$ ) reached $53 \%$ [13]. Impact of renal dysfunction in the elderly was evaluated in 1904 patients from 75 years and over presenting with ACS. Patients were classified in three groups based on the eGFR: $\geq 60,30-59$ and $<30 \mathrm{~mL} / \mathrm{min} / 1.73 \mathrm{~m}^{2}$. For hospitalized patients, mortality was $1.1 \%, 2.1 \%$ and $4.4 \%(p=0.015)$ while after discharge, all-cause mortality was $3.4 \%, 5.2 \%$ and $12.8 \%(p<$ $0.001)$, respectively [36]. Recurrence of non-fatal myocardial infarction (MI) disabling stroke and bleeding was similar between CKD and no-CKD groups. Patients with eGFR less than $30 \mathrm{~mL} / \mathrm{min} / 1.73 \mathrm{~m}^{2}$ were older, hypertensive, diabetic, with peripheral artery disease, multivessel coronary disease artery, with heart failure with reduced ejection fraction and with anemia [36].

\section{CKD and therapeutic options in ACS}

Patients with CKD have been frequently excluded from ACS trials [37]. While the decision-making for patients admitted with ACS ST-elevation requires invasive revascularization when feasible, managing patients with ACS without persistent ST-elevation with CKD is challenging for a lack of evidence. In a retrospective analysis from SWEDEHEART data, the incidence of coronary revascularization and its effect on mortality were evaluated in 23,262 ACS patients aged $\leq 80$ years. Rates of coronary angiography and invasive revascularization were low in patients with a reduced renal function. For instance, in the severe eGFR reduction/dialyzed group, only $12 \%$ of patients underwent PCI and only 3\% received coronary artery bypass graft (CABG). An improvement of 1-year survival was observed in patients with mild-to-moderate CKD (eGFR $>30 \mathrm{~mL} / \mathrm{min} / 1.73 \mathrm{~m}^{2}$ ) treated with early revascularization (within 14 days of admission). Less benefits and a trend toward harm were observed in the lower renal function group (eGFR $<30 \mathrm{~mL} / \mathrm{min} / 1.73 \mathrm{~m}^{2}$ ) [38]. Current guidelines for non-ST- elevation myocardial infarction (NSTEMI) recom- mend, with a class of evidence IIa/level B, surgical revascularization over PCI in patients with moderate to severe CKD with multivessel coronary disease, a high surgical risk profile and a life expectancy of $>1$ year [32]. This recommendation is based mostly on old data from previous generation of stent and antithrombotic treatments.

A more recent retrospective study from the SWEDEHEART registry included ACS patients $>80$ years with CKD, defined as an eGFR $<60 \mathrm{~mL} / \mathrm{min} / 1.73 \mathrm{~m}^{2}$, hospitalized in Sweden from 2011 to 2014. Cox regression was used to estimate all-cause mortality in patients with PCI versus conservative treatment, classified according to the eGFR. Patients invasively treated had a lower risk of death in all groups of eGFR, underling the benefit of this strategy. Higher bleeding events with PCI were observed only in the group of patients with eGFR 15 to $<30 \mathrm{~mL} / \mathrm{min} / 1.73 \mathrm{~m}^{2}$ [39].

A meta-analysis of comparative studies carried out between 1995 and 2010 analysing the effect of early revascularization in patients with NSTEMI and CKD, showed interesting benefits from early revascularization on shortand long-term mortality. Specifically, a reduction in 1-year mortality compared to initial medical therapy $(\mathrm{OR}=0.46$, 95\% CI $0.26-0.82, p=0.008)$ among ACS patients with eGFR $>60 \mathrm{~mL} / \mathrm{min} / 1.73 \mathrm{~m}^{2}$ was observed. In addition, the effects of 1-year mortality reduction were also observed, after early revascularization, in patients with moderate and severe CKD and end-stage renal dysfunction (ESRD). Although patients with ESRD (39.8\%) had a higher risk of 1-year all-cause mortality than those with at least moderate CKD (25.1\%), the first group presented a higher absolute risk reduction in 1-year mortality with early revascularization compared to the second one $(21.3 \%$ vs. $16.6 \%$ respectively). These results confirm that the sickest patients could have more benefits from early revascularization [43]. Even though revascularization in this group of patients would be conceptually beneficial, it should be emphasized that most of the evidence derives from registries and meta-analysis. Therefore, further and larger studies are needed to confirm the clinical benefits of the invasive strategy in ACS patients with CKD [44].

The Academic Research Consortium for High Bleeding Risk (ARC-HBR) recognizes severe or end-stage CKD (eGFR $<30 \mathrm{~mL} / \mathrm{min} / 1.73 \mathrm{~m}^{2}$ ) as major risk factor for bleeding [45]. On the other hand, as previously discussed, CKD has an elevated ischemic risk. However, neither eGFR nor serum creatinine level were included in DAPT score as ischemic risk score for prolonged dual antiplatelet therapy (DAPT).

DAPT is highly recommended in ACS patients to improve outcome and prognosis, regardless of renal function. However, the efficacy and safety of antithrombotic drugs with potent P2Y12 inhibitors, a chemoreceptor for platelets released adenosine diphosphate (ADP), in patients with severe CKD or ESRD are not clearly evaluated, since 


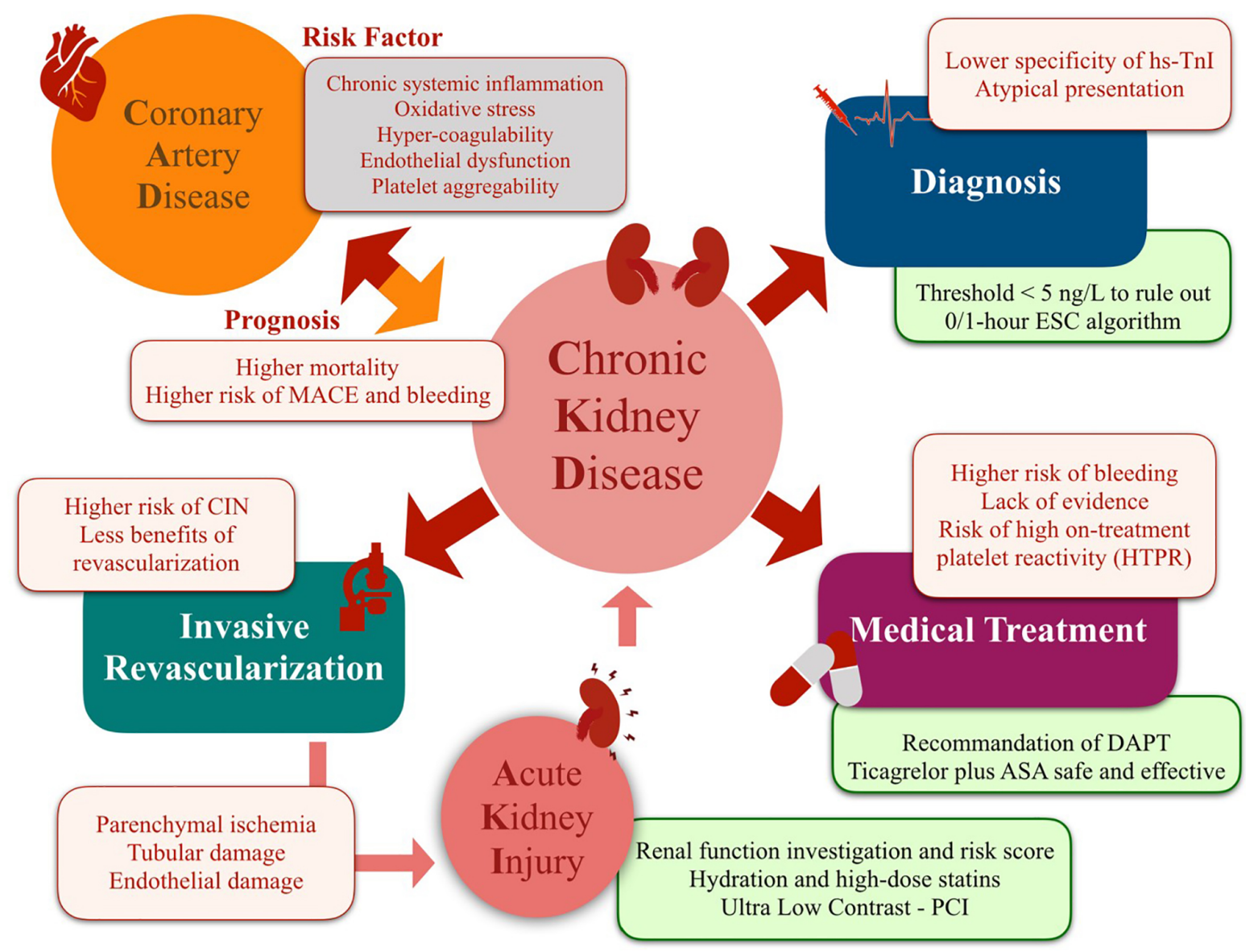

Fig. 1. Kidney dysfunction and acute coronary syndrome.

these patients are frequently excluded from randomized controlled trials [46]. In patient with ACS and CKD there are no contraindications for aspirin, no dose adjustment is required if renal function is reduced $[47,48]$. Clopidogrel is a prodrug and need activation to bind the ADP receptor. Standard dose of clopidogrel has a lower inhibition of ADPinduced platelet aggregation $(-25 \%)$ in patients with depressed renal function, and is associated with greater prevalence of high on-treatment platelet reactivity (HTPR), leading to an increased ischemic risk [49,50]. In the ARTIC study, 2440 patients were randomized before drug-eluting stent implantation, both using a strategy of platelet function monitoring and without monitoring. In the monitoring group, $35 \%$ of patients had high platelet reactivity (HPR) to clopidogrel [51]. Patients with CKD have a higher risk of HTPR, with an increased rate in lower renal function groups. However, after multivariable adjustment, no significant association was detected between HTPR and CKD, suggesting that risk factors account for HPR in patients with renal impairment [52]. Post hoc analyses of CREDO trial (Clopidogrel for the Reduction of Events During Observation) show a limited efficacy, defined as death, myocardial infarction or stroke, and higher risk of bleeding, after 1 year of clopidogrel vs. placebo in patients with mild to moderate CKD [52]. Similar findings were observed in other analy- ses $[53,54]$. Several studies show the superiority of potent oral P2Y12-ADP receptor antagonists, ticagrelor and prasugrel, over clopidogrel in CKD patients [55-58]. Despite the clinical benefits of potent P2Y12-ADP receptor antagonists over clopidogrel in patients with ACS [59,60], clinical and therapeutic experience with prasugrel and ticagrelor is limited in patients with renal impairment (including patients with ESRD).

In the subgroup analysis of the TRITON TIMI 38 trial, including 1490 patients with a eGFR $<60 \mathrm{~mL} / \mathrm{min} / 1.73$ $\mathrm{m}^{2}$, the benefit of prasugrel over clopidogrel was constant across the the overall population. However, there are no specific data regarding bleeding end point in patients with $\mathrm{CKD}$, but, in the overall trial population, prasugrel increased the rate of major non-CABG related Trombolysis in Myocardial Infarction (TIMI) bleeding [59]. In the PROMETHEUS registry, 19,832 patients ACS patients undergoing PCI under clopidogrel or prasugrel have been included $(28.3 \%$ with a creatinine clearance $<60 \mathrm{~mL} / \mathrm{min})$. After propensity adjustment, prasugrel did not confer significant benefit compared to to clopidogrel with respect to the incidence of a composite of end point including death, MI, stroke, and urgent revascularization at 1 year in the CKD subgroup, with a similar rate of bleedings [40]. 
Table 1. Studies showing impact of kidney dysfunction in acute coronary syndrome.

\begin{tabular}{|c|c|c|c|c|}
\hline Authors & $\mathrm{n}$ & Aims and groups & Primary endpoint & Secondary endpoints \\
\hline Go et al. [2], 2004 & $1,120,295$ & $\begin{array}{l}\text { Correlation between the GFR and risks of death, } \\
\text { CV events, and hospitalization. } \\
\text { Results related to group of eGFR }(45-59,30- \\
\left.44,15-29 \text {, and }<15 \mathrm{~mL} / \mathrm{min} / 1.73 \mathrm{~m}^{2}\right) \text {. }\end{array}$ & $\begin{array}{l}\text { HR for death: } 1.2(95 \% \text { CI } 1.1-1.2), 1.8(95 \% \\
\text { CI } 1.7-1.9), 3.2(95 \% \text { CI } 3.1-3.4) \text {, and } 5.9(95 \% \\
\text { CI 5.4-6.5), inversely related to GFR. } \\
\text { HR for MACE: } 1.4(95 \% \text { CI 1.4-1.5), } 2.0(95 \% \\
\text { CI } 1.9-2.1), 2.8 \text { ( } 95 \% \text { CI } 2.6-2.9) \text {, and } 3.4(95 \% \\
\text { CI 3.1-3.8), respectively. }\end{array}$ & $\begin{array}{l}\text { HR for Any Hospitalization: } 1.1 \text { (95\% CI } 1.1- \\
1.1), 1.5(95 \% \text { CI } 1.5-1.5), 2.1 \text { (95\% CI } 2.0-2.2) \text {, } \\
\text { and } 3.1 \text { (95\% CI 3.0-3.3), respectively. }\end{array}$ \\
\hline Fox et al. [30], 2012 & $59,970(100 \%$ with ACS $)$ & $\begin{array}{l}\text { To examine in-hospital all cause death and ma- } \\
\text { jor bleeding in patients with AKI in setting of } \\
\text { MI. } \\
\text { Classification as absolute change in sCr: mild } \\
\text { ( } \mathrm{sCr} 0.3-0.5 \mathrm{mg} / \mathrm{dL} \text { ), moderate ( } \mathrm{SCr} 0.5-1.0 \text { ), } \\
\text { and severe } \mathrm{AKI}(\mathrm{SCr} \geq 1.0 \text { ). }\end{array}$ & $\begin{array}{l}\text { OR: } 2.4(95 \% \text { CI } 2.0-2.7) \text { for mild AKI; } 4.5 \\
\text { (95\% CI 3.9-5.1) for moderate AKI; } 12.6(95 \% \\
\text { CI } 11.1-14.3) \text { for severe AKI. }\end{array}$ & $\begin{array}{l}\text { Crude rates of major bleeding: mild AKI } 16.5 \% \text {, } \\
\text { moderate AKI } 22.6 \% \text { and severe AKI } 32.7 \% \text {. }\end{array}$ \\
\hline $\begin{array}{l}\text { De Rosa et al. [36], } \\
2020\end{array}$ & 1904 (100\% with ACS) & $\begin{array}{l}\text { Correlation between contrast induced-AKI and } \\
\text { adverse one-year outcome in elderly patients } \\
\text { (mean age } 81.0 \pm 4.6 \text { years). Stratification ac- } \\
\text { cording to eGFR }(59-30 ; 30-15 ;<15 \mathrm{~mL} / \mathrm{min} / \\
1.73 \mathrm{~m}^{2} \text { ). }\end{array}$ & $\begin{array}{l}\text { Risk of all-cause mortality at } 12 \text { months: } 4.5 \% \text {, } \\
7.5 \% \text { and } 17.8 \% \text { inversely related to GFR ( } p< \\
0.001) \text {. } \\
\text { Risk of CV mortality at } 12 \text { months: }(2.8 \%, 5.2 \% \\
\text { and } 10.2 \% \text {, respectively). }\end{array}$ & $\begin{array}{l}\text { Severe contrast induced-AKI is associated with } \\
\text { a higher risk of all-cause (HR 2.86, 95\% CI } \\
1.52-5.37, p=0.001) \text { and CV death (HR } 3.11 \text {, } \\
95 \% \text { CI } 1.41-6.83, p=0.005) \text {. } \\
\text { Contrast induced-AKI incidence significantly } \\
\text { higher in STEMI vs. NSTEMI }(11.7 \% \text { vs. } \\
7.8 \%, p=0.036) \text {. }\end{array}$ \\
\hline $\begin{array}{l}\text { Charytan et al. [37], } \\
2006\end{array}$ & $154,692(100 \%$ with ACS $)$ & $\begin{array}{l}\text { To indagate use of coronary angiography }(\mathrm{CA}) \\
\text { and PCI in patients with CKD }(\mathrm{n}=8957) \text { dialy- } \\
\text { sis }(\mathrm{n}=2369) \text {. }\end{array}$ & $\begin{array}{l}\text { Rate of CABG or PCI was } 19.2 \% \text { in dialyzed pa- } \\
\text { tients, } 23.0 \% \text { in patients with CKD, and } 41.4 \% \\
\text { in control group (RR } 0.46 \text { [ } 95 \% \text { CI } 0.42-0.52] \\
\text { and } 0.56 \text { [ } 95 \% \text { CI } 0.53-0.59] \text { respectively). } \\
\text { Rates of diagnostic CA were } 38.6 \% \text { in dialyzed } \\
\text { patients (RR } 0.68,95 \% \text { CI } 0.64-0.73 \text { ), } 34 \% \text { in } \\
\text { patients with CKD (RR } 0.62,95 \% \text { CI } 0.59- \\
0.64 \text { ) than in control ( } 56.6 \%) \text {. }\end{array}$ & $\begin{array}{l}\text { Rate of CABG or PCI after CA was } 46.4 \% \text { (RR } \\
0.66,95 \% \text { CI } 0.61-0.72) \text { in dialysis patients, } \\
61.6 \% \text { (RR } 0.88,95 \% \text { CI } 0.86-0.90) \text { in patients } \\
\text { with CKD, and } 70.1 \% \text { in control group. }\end{array}$ \\
\hline $\begin{array}{l}\text { Szummer et al. } \\
{[38], 2009}\end{array}$ & $\begin{array}{l}23,262 \text { patients }(100 \% \text { with } \\
\text { NST-ACS })\end{array}$ & $\begin{array}{l}\text { To investigate } 1 \text { year outcome after early in- } \\
\text { vasive management in NSTEMI patients with } \\
\text { CKD. }\end{array}$ & $\begin{array}{l}\text { No benefit for PCI in advanced CKD (eGFR } \\
<15 \mathrm{~mL} / \mathrm{min} / 1.73 \mathrm{~m}^{2} \text { ) or in dialysis (HR } 1.61 \text {, } \\
95 \% \mathrm{CI} 0.84 \text { to } 3.09, p=0.15 \text { ). }\end{array}$ & $\begin{array}{l}\text { Rate of patients treated invasively with de- } \\
\text { clining renal function: from } 62 \% \text { with eGFR } \\
\geq 90 \mathrm{~mL} / \mathrm{min} / 1.73 \mathrm{~m}^{2} \text {, to } 15 \% \text { with eGFR }<15 \\
\mathrm{~mL} / \mathrm{min} / 1.73 \mathrm{~m}^{2} \text { or in dialysis, }(p<0.001)\end{array}$ \\
\hline
\end{tabular}


Table 1. Continued.

\begin{tabular}{|c|c|c|c|c|}
\hline Authors & $\mathrm{n}$ & Aims and groups & Primary endpoint & Secondary endpoints \\
\hline \multirow[t]{2}{*}{$\begin{array}{l}\text { Holzmann et al. } \\
\text { [39], } 2020\end{array}$} & \multirow[t]{2}{*}{$\begin{array}{l}12,821 \text { patients }(100 \% \text { with } \\
\text { NST-ACS })\end{array}$} & $\begin{array}{l}\text { Benefit of PCI in NSTEMI for elderly patients } \\
\text { (mean age } 86 \text { years old) with CKD. }\end{array}$ & $\begin{array}{l}\text { Absolute risk of death was } 42 \%, 56 \% \text {, and } 76 \% \text {, } \\
\text { respectively. }\end{array}$ & $\begin{array}{l}\text { OR for in hospital re-IMA: } 1.76(0.71-4.37) \text {, } \\
1.89(0.95-3.76), 3.03(0.90-10.22) \text {, respec- } \\
\text { tively. }\end{array}$ \\
\hline & & $\begin{array}{l}\text { Stratification related to eGFR: }>60,60-30 \text { and } \\
<30 \mathrm{~mL} / \mathrm{min} / 1.73 \mathrm{~m}^{2} .\end{array}$ & $\begin{array}{l}\text { HR death risk after PCI was lower all groups: } \\
0.47 \text { [95\% CI } 0.42-0.53], 0.50 \text { [95\% CI } 0.45- \\
0.56] \text {, and } 0.44 \text { [95\% CI } 0.33-0.59 \text { ], respec- } \\
\text { tively. }\end{array}$ & $\begin{array}{l}\text { OR for in hospital bleeding: } 1.62(0.86-3.08) \text {, } \\
1.22(0.73-2.03), 2.77(1.03-7.49) \text {. }\end{array}$ \\
\hline $\begin{array}{l}\text { James et al. [40], } \\
2010\end{array}$ & $15,202(100 \%$ with ACS $)$ & $\begin{array}{l}\text { Efficacy and safety of ticagrelor vs. clopidogrel } \\
\text { in relation to renal function. }\end{array}$ & $\begin{array}{l}\text { In patients with } \mathrm{CKD} \text {, ticagrelor vs clopidogrel } \\
\text { reduced the composite endpoint (CV death, MI } \\
\text { and stroke) from } 22.0 \% \text { to } 17.3 \% \text { (HR, } 0.77 \text {; } \\
95 \% \text { CI } 0.65 \text { to } 0.90) \text {. }\end{array}$ & $\begin{array}{l}\text { Major bleeding rates, not different ( } 15.1 \% \text { vs. } \\
14.3 \% \text {; HR, } 1.07 ; 95 \% \text { CI } 0.88-1.30) \text {. }\end{array}$ \\
\hline $\begin{array}{l}\text { De Filippo et al. } \\
\text { [41], } 2020\end{array}$ & 19,255 (100\% with ACS) & $\begin{array}{l}\text { Safety and efficacy profile of prasugrel and tica- } \\
\text { grelor in real-life ACS patients with CKD. }\end{array}$ & $\begin{array}{l}\text { Prasugrel and ticagrelor reduced the mortality } \\
\text { rate (HR } 0.82,95 \% \text { CI } 0.54-0.96 ; p=0.006 \text { ) and } \\
\text { the risk of reinfarction (HR } 0.53,95 \% \mathrm{CI} 0.30- \\
0.95 ; p=0.033 \text { ) in CKD patients as compared } \\
\text { to clopidogrel. }\end{array}$ & $\begin{array}{l}\text { DAPT with either ticagrelor or prasugrel did not } \\
\text { result in an increased risk of major bleedings in } \\
\text { CKD patients (HR 1.00, } 95 \% \text { CI } 0.59-1.68 ; p= \\
0.985 \text { ). }\end{array}$ \\
\hline \multirow{4}{*}{$\begin{array}{l}\text { Valle McCoy et al. } \\
\text { [42], } 2017\end{array}$} & \multirow[t]{4}{*}{453,475 (66.95\% with ACS) } & $\begin{array}{l}\text { Contrast induced-AKI after PCI, risk and prog- } \\
\text { nosis. }\end{array}$ & Rate of Contrast induced-AKI was $8.8 \%$. & $\begin{array}{l}\text { Re-Hosp for AKI: AKIN 1, HR } 1.70 \text { (95\% CI } \\
\text { 1.64-1.76); AKIN 2/3: HR } 2.22 \text { (95\% CI 2.04- } \\
\text { 2.41). }\end{array}$ \\
\hline & & AKIN stages: & $\begin{array}{l}\text { Primary outcome (death, MI, or bleeding within } \\
1 \text { year of hospital discharge): }\end{array}$ & $\begin{array}{l}\text { Dialysis: AKIN } 1 \text { HR, } 2.59 \text { (95\% CI } 2.29- \\
\text { 2.92); AKIN 2/3 HR, } 4.73 \text { (95\% CI 3.73-5.99). }\end{array}$ \\
\hline & & $\begin{array}{l}\text { 1. as a } \geq 0.3 \mathrm{mg} / \mathrm{dL} \text { absolute or } 1.5 \text { - to } 2.0 \text {-fold } \\
\text { relative increase in } \mathrm{sCr} \text {; }\end{array}$ & AKIN 1: HR 1.53; (95\% CI 1.49-1.56). & $\begin{array}{l}\text { MI: AKIN stage } 2 / 3: \text { HR, } 1.29 \text { (95\% CI } 1.15- \\
\text { 1.45); AKIN stage } 1 \text { HR } 1.32 \text { ( } 95 \% \text { CI } 1.26- \\
\text { 1.38). }\end{array}$ \\
\hline & & $\begin{array}{l}\text { 2. as a }>2 \text { - to } 3 \text {-fold increase in } \mathrm{sCr} \text {; } \\
\text { 3. as a } \mathrm{SCr} \text { creatinine }>4.0 \mathrm{mg} / \mathrm{dL} \text { with an acute } \\
\text { increase of } \geq 0.5 \mathrm{mg} / \mathrm{dL} \text { or a }>3 \text {-fold increase. }\end{array}$ & AKIN 2/3: HR 2.13; (95\% CI 2.01-2.26). & $\begin{array}{l}\text { Bleeding: AKIN stage } 2 / 3: \mathrm{HR}, 1.40 ; 95 \% \mathrm{CI} \\
1.19-1.66 \text {; AKIN stage } 1: \mathrm{HR}, 1.31 ; 95 \% \mathrm{CI} \\
1.23-1.40 \text { ). }\end{array}$ \\
\hline
\end{tabular}


In a multicenter, retrospective, observational study from BleeMACS and RENAMI the benefits and safety of potent $\mathrm{P} 2 \mathrm{Y} 12$ inhibitors in $\mathrm{CKD}$ and ACS patients were investigated. In 19,255 CKD patients $(12.9 \%$ with eGFR $<60$ $\mathrm{mL} / \mathrm{min} / 1.73 \mathrm{~m}^{2}$ ), prasugrel and ticagrelor significantly reduced the mortality rate [HR $0.82,95 \%$ CI $0.54-0.96 ; p=$ 0.006 ] and the risk of reinfarction [HR $0.53,95 \%$ CI 0.30 0.95; $p=0.033$ ] compared to clopidogrel. Potent P2Y12 inhibitors appeared to be safe and did not increase the risk of major bleeding in CKD patients [HR 1.00, 95\% CI 0.59$1.68 ; p=0.985$ ] [61]. In a subgroup analysis from PLATO trial, patients with renal impairment, defined as eGFR $<60$ $\mathrm{mL} / \mathrm{min} / 1.73 \mathrm{~m}^{2}$, constituted $21 \%$ of those with baseline creatinine measurements, while patients with ESRD requiring dialysis were excluded. Treatment with ticagrelor significantly reduced the primary endpoint (a composite of cardiovascular death, myocardial infarction, and stroke at 1 year) from $22 \%$ to $17.3 \%$. No significant increase in major bleeding was reported [60]. Evaluation of this treatment in patients with ESRD are ongoing [41].

In recent years, the attention has been focused on intravenous antiplatelet drugs, which offer a reduction of ischemic events in patients with ACS undergoing PCI. These drugs play a central role extending from perioperative bridging to planned surgery that requires stop of oral P2Y12 antagonist. Two classes of drugs can be defined: glycoprotein IIb/IIIa inhibitors (GPIs) (abciximab, tirofiban, and eptifibatide) and Cangrelor. GPIs block glycoprotein IIb/IIIa receptors on platelet's plasma membrane, preventing the binding of fibrinogen and thus platelet aggregation [31]. Tirofiban and Eptifibatide are renally eliminated and need dosage adjustment if used in patients with CKD. Explicit contraindications exist when used in patients with eGFR less than $15 \mathrm{~mL} / \mathrm{min} / 1.73 \mathrm{~m}^{2}$. On the other hand, tirofiban can be used in stage 4 CKD (eGFR 15 to $30 \mathrm{~mL} / \mathrm{min} / 1.73 \mathrm{~m}^{2}$ ) with a reduced infusion rate to $50 \%$ [62]. Abciximab is not renally eliminated and does not need any adjustments of its dosage for CKD [63]. Several subgroup analyses have confirmed that bleeding is increased in patients who are receiving GPIs and present CKD, especially when the dosage of GPIs is not adjusted for CKD [64]. Cangrelor is the only currently available intravenous platelet P2Y12 receptor inhibitor, with a quickly and reversible platelet inhibition. Cangrelor was approved for patients undergoing PCI for its benefits in reducing ischemic events, including stent thrombosis, and for no detectable increase of major bleeding, versus clopidogrel [65]. Basing on pharmacologic properties [66], cangrelor is indicated in P2Y12 receptor inhibitor-naïve patients undergoing PCI [32] or as bridge therapy in patients undergoing non-cardiac surgery with recent coronary stent. Cangrelor infusion rate is bolus of $30 \mathrm{mcg} / \mathrm{kg}$ i.v., followed by a $4 \mathrm{mcg} / \mathrm{kg} / \mathrm{min}$ infusion for at least 2 hours or until the end of the procedure, if not longer [31]. Since no dose adjustment is required in patients with $\mathrm{CKD}$, cangrelor may be considered as a first choice in patients with ACS and CKD if an intravenous antiplatelet agent is needed during PCI [62].

When administered within the first 24 hours, angiotensin-converting enzyme inhibitors (ACE-I) and angiotensin receptor blockers (ARB) are fundamental compounds of post-MI therapy for reducing fatal and nonfatal MACE [61,65]. Nevertheless, evidence is less robust in CKD patients, since there is not a clear cut-off level of $\mathrm{sCr}$ that contraindicates the use of these agents [65]. Both ESC and American Heart Association (AHA) STEMI guidelines, state that renal dysfunction should be taken into account as a contraindication for their routine use of ACE-I or ARB [66-71].

There is a paucity of evidence about the use of Sacubitril/Valsartan in patients with CKD and ACS. A recent randomized trial, PARADISE-MI, did not find any statistical significance in MACE rate with the initiation of sacubitril/valsartan therapy vs ramipril in patients with a high risk of heart failure surviving an ACS, regardless of moderate CKD presence (defined as eGFR $<60$ and $>30$ $\mathrm{mL} / \mathrm{min} / 1.73 \mathrm{~m}^{2}$ ) [72].

Sodium-glucose cotransporter-2 inhibitors (SGLT2i) represent a new class of oral hypoglycemic agents used for the treatment of heart failure with reduced ejection fraction, regardless of the presence of DM. To date, evidence about the favorable outcome in CKD patients with ACS treated with SGLT2 $\mathrm{i}$ is scarce. However, several studies have found a better renal outcome in DM patients with CKD treated with canagliflozin [73] and dapagliflozin [74]. An ongoing study is investigating the use of SGLT2 $\mathrm{i}$ in DM patients with ACS (ClinicalTrials.gov Identifier: CT0503705; ClinicalTrials.gov Identifier: NCT05037058).

\section{Conclusions}

A high ischemic risk and rate of AMI occur in CKD patients, with an even higher prevalence in dialyzed patients. Both cardiac and kidney dysfunction may worsen the prognosis and lead to disease progression. Therapeutic strategies employed in ACS can expose CKD patients to higher rates of major and fatal bleeding. This condition leads to an undertreatment attitude and to a conservative approach for patients with renal impairment. Patients with CKD are less frequently treated with percutaneous or surgical revascularization even thought they could potentially benefit from a more invasive management. Moreover, the use of potent P2Y12-ADP antagonists could be considered a significant advantage for CKD patients. Further clinical studies are needed to assess the best treatment strategies for this high-risk subset of patients.

\section{Author contributions}

Systematic review of literature-LDL, VF, MDM. Drafting and final approval-LDL, RM and FAV. 


\section{Ethics approval and consent to participate}

Not applicable.

\section{Acknowledgment}

The authors thank to Alessandra Picariello, in quality of professional English language revisor, for her contribution to the linguistic revision of the manuscript.

\section{Funding}

This research received no external funding.

\section{Conflict of interest}

The authors declare no conflict of interest. Leonardo De Luca is serving as one of the Editorial Board members of this journal. We declare that Leonardo De Luca had no involvement in the peer review of this article and has no access to information regarding its peer review. Full responsibility for the editorial process for this article was delegated to Carlo Briguori.

\section{References}

[1] Ather S, Chan W, Bozkurt B, Aguilar D, Ramasubbu K, Zachariah AA, et al. Impact of Noncardiac Comorbidities on Morbidity and Mortality in a Predominantly Male Population with Heart Failure and Preserved Versus Reduced Ejection Fraction. Journal of the American College of Cardiology. 2012; 59: 998-1005.

[2] Go AS, Chertow GM, Fan D, McCulloch CE, Hsu CY. Chronic Kidney Disease and the Risks of Death, Cardiovascular Events, and Hospitalization. New England Journal of Medicine. 2004; 351: 1296-1305.

[3] Cai Q, Mukku VK, Ahmad M. Coronary Artery Disease in Patients with Chronic Kidney Disease: a Clinical Update. Cur-rent Cardiology Reviews. 2013; 9: 331-339.

[4] Sosnov J, Lessard D, Goldberg RJ, Yarzebski J, Gore JM. Differential Symptoms of Acute Myocardial Infarction in Pa-tients with Kidney Disease: a Community-Wide Perspective. American Journal of Kidney Diseases. 2006; 47: 378-384.

[5] Wanner C, Tonelli M. KDIGO Clinical Practice Guideline for Lipid Management in CKD: summary of recommendation statements and clinical approach to the patient. Kidney International. 2014; 85: 1303-1309.

[6] Mamoulakis C, Tsarouhas K, Fragkiadoulaki I, Heretis I, Wilks MF, Spandidos DA, et al. Contrast-induced nephropathy: Basic concepts, pathophysiological implications and prevention strategies. Pharmacology \& Therapeutics. 2017; 180: 99-112.

[7] Faggioni M, Mehran R. Preventing Contrast-induced Renal Failure: a Guide. Interventional Cardiology. 2016; 11: 98-104.

[8] Seeliger E, Lenhard DC, Persson PB. Contrast Media Viscosity versus Osmolality in Kidney Injury: Lessons from Animal Studies. BioMed Research International. 2014; 2014: 358136.

[9] Persson PB, Hansell P, Liss P. Pathophysiology of contrast medium-induced nephropathy. Kidney International. 2005; 68: $14-22$.

[10] Keaney JJ, Hannon CM, Murray PT. Contrast-induced acute kidney injury: how much contrast is safe? Nephrology Dial-ysis Transplantation. 2013; 28: 1376-1383.

[11] Briguori C, Colombo A, Airoldi F, Melzi G, Michev I, Carlino $\mathrm{M}$, et al. Gadolinium-based contrast agents and nephrotoxicity in patients undergoing coronary artery procedures. Catheterization and Cardiovascular Interventions. 2006; 67: 175-180.
[12] Lameire N, Adam A, Becker CR, Davidson C, McCullough PA, Stacul F, et al. Baseline Renal Function Screen-ing. The American Journal of Cardiology. 2006; 98: 21K-26K.

[13] Giacoppo D, Madhavan MV, Baber U, Warren J, Bansilal $\mathrm{S}$, Witzenbichler B, et al. Impact of Contrast-Induced Acute Kidney Injury after Percutaneous Coronary Intervention on Short- and Long-Term Outcomes: Pooled Analysis From the HORIZONS-AMI and ACUITY Trials. Circulation: Cardiovascular Interventions. 2015; 8: e002475.

[14] Mehran R, Aymong ED, Nikolsky E, Lasic Z, Iakovou I, Fahy $\mathrm{M}$, et al. A simple risk score for prediction of con-trast-induced nephropathy after percutaneous coronary intervention: Development and initial validation. Journal of the American College of Cardiology. 2004; 44: 1393-1399.

[15] Brar SS, Aharonian V, Mansukhani P, Moore N, Shen AY, Jorgensen $\mathrm{M}$, et al. Haemodynamic-guided fluid ad-ministration for the prevention of contrast-induced acute kidney injury: the POSEIDON randomised controlled trial. The Lancet. 2014; 383: 1814-1823.

[16] Briguori C, Visconti G, Focaccio A, Airoldi F, Valgimigli M, Sangiorgi GM, et al. Renal Insufficiency after Con-trast Media Administration Trial II (REMEDIAL II): RenalGuard System in high-risk patients for contrast-induced acute kidney injury. Circulation. 2011; 124: 1260-1269.

[17] Marenzi G, Ferrari C, Marana I, Assanelli E, De Metrio M, Teruzzi G, et al. Prevention of Contrast Nephropathy by Furosemide with Matched Hydration: the MYTHOS (Induced Diuresis With Matched Hydration Compared to Standard Hydration for Contrast Induced Nephropathy Prevention) trial. JACC: Cardiovascular Interventions. 2012; 5: 90-97.

[18] Giacoppo D, Gargiulo G, Buccheri S, Aruta P, Byrne RA, Cassese $\mathrm{S}$, et al. Preventive Strategies for Contrast-Induced Acute Kidney Injury in Patients Undergoing Percutaneous Coronary Procedures: Evidence from a Hierarchical Bayesian Network Meta-Analysis of 124 Trials and 28240 Patients. Circulation: Cardiovascular Interventions. 2017; 10: e004383.

[19] Cho A, Lee YK, Sohn SY. Beneficial effect of statin on preventing contrast-induced acute kidney injury in patients with renal insufficiency: a meta-analysis. Medicine. 2020; 99: e19473.

[20] Toso A, Leoncini M, Maioli M, Tropeano F, Di Vincenzo E, Villani S, et al. Relationship between Inflammation and Benefits of Early High-Dose Rosuvastatin on Contrast-Induced Nephropathy in Patients with Acute Coronary Syndrome: the pathophysiological link in the PRATO-ACS study (Protective Effect of Rosuvastatin and Antiplatelet Therapy on ContrastInduced Nephropathy and Myocardial Damage in Patients With Acute Coronary Syndrome Undergoing Coronary Intervention). JACC: Cardiovascular Interventions. 2014; 7: 1421-1429.

[21] Neumann FJ, Sousa-Uva M, Ahlsson A, Alfonso F, Banning AP, Benedetto U, et al. 2018 ESC/EACTS Guide-lines on myocardial revascularization. European Heart Journal. 2019; 40: 87165.

[22] Jo SH, Youn TJ, Koo BK, Park JS, Kang HJ, Cho YS, et al. Renal Toxicity Evaluation and Comparison between Visipaque (Iodixanol) and Hexabrix (Ioxaglate) in Patients with Renal Insufficiency Undergoing Coronary Angiography: the RE-COVER study: a randomized controlled trial. Journal of the American College of Cardiology. 2006; 48: 924-930.

[23] Liss P, Persson PB, Hansell P, Lagerqvist B. Renal failure in 57925 patients undergoing coronary procedures using isoosmolar or low-osmolar contrast media. Kidney International. 2006; 70: 1811-1817.

[24] Mehran R, Faggioni M, Chandrasekhar J, Angiolillo DJ, Bertolet B, Jobe RL, et al. Effect of a Contrast Modula-tion System on Contrast Media Use and the Rate of Acute Kidney Injury after 
Coronary Angiography. JACC: Cardiovascular In-terventions. 2018; 11: 1601-1610.

[25] Briguori C, Golino M, Porchetta N, Scarpelli M, De Micco F, Rubino C, et al. Impact of a contrast media volume control device on acute kidney injury rate in patients with acute coronary syndrome. Catheterization and Cardiovascular Interven-tions. 2021; 98: 76-84.

[26] Nayak KR, Mehta HS, Price MJ, Russo RJ, Stinis CT, Moses $\mathrm{JW}$, et al. A novel technique for ultra-low contrast administration during angiography or intervention. Catheterization and Cardiovascular Interventions. 2010; 75: 1076-1083.

[27] Azzalini L, Laricchia A, Regazzoli D, Mitomo S, Hachinohe $\mathrm{D}$, Bellini $\mathrm{B}$, et al. Ultra-Low Contrast Percutaneous Coronary Intervention to Minimize the Risk for Contrast-Induced Acute Kidney Injury in Patients With Severe Chronic Kidney Disease. Journal of Interventional Cardiology. 2019; 31: 176-182.

[28] Ali ZA, Karimi Galougahi K, Nazif T, Maehara A, Hardy MA, Cohen DJ, et al. Imaging- and physiology-guided percutaneous coronary intervention without contrast administration in advanced renal failure: a feasibility, safety, and outcome study. European Heart Journal. 2016; 37: 3090-3095.

[29] Mariani J, Guedes C, Soares P, Zalc S, Campos CM, Lopes AC, et al. Intravascular Ultrasound Guidance to Min-imize the Use of Iodine Contrast in Percutaneous Coronary Intervention: the MOZART (Minimizing cOntrast utiliZation With IVUS Guidance in coRonary angioplasTy) randomized controlled trial. JACC: Cardiovascular Interventions. 2014; 7: 1287-1293.

[30] Santopinto JJ, Fox KA, Goldberg RJ, Budaj A, Piñero G, Avezum A, et al. Creatinine clearance and adverse hos-pital outcomes in patients with acute coronary syndromes: findings from the global registry of acute coronary events (GRACE). Heart. 2003; 89: 1003-1008.

[31] Anavekar NS, McMurray JJ, Velazquez EJ, Solomon SD, Kober $\mathrm{L}$, Rouleau J, et al. Relation between Renal Dys-function and Cardiovascular Outcomes after Myocardial Infarction. New England Journal of Medicine. 2004; 351: 1285-1295.

[32] Collet JP, Thiele H, Barbato E, Barthélémy O, Bauersachs J, Bhatt DL, et al. 2020 ESC Guidelines for the man-agement of acute coronary syndromes in patients presenting without persistent ST-segment elevation. European Heart Journal. 2021: 42: $1289-1367$.

[33] Miller-Hodges E, Anand A, Shah A, Chapman AR, Gallacher P, Lee KK, et al. High-Sensitivity Cardiac Troponin and the Risk Stratification of Patients with Renal Impairment Presenting with Suspected Acute Coronary Syndrome. Circulation. 2018; 137: 425-435.

[34] Ren D, Huang T, Liu X, Xu G. High-sensitive cardiac troponin for the diagnosis of acute myocardial infarction in differ-ent chronic kidney disease stages. BMC Cardiovascular Disorders. 2021; 21: 100 .

[35] Twerenbold R, Badertscher P, Boeddinghaus J, Nestelberger T, Wildi K, Puelacher C, et al. 0/1-Hour Triage Algo-rithm for Myocardial Infarction in Patients with Renal Dysfunction. Circulation. 2018 ; 137: 436-451.

[36] De Rosa R, Morici N, De Servi S, De Luca G, Galasso G, Piscione $\mathrm{F}$, et al. Impact of renal dysfunction and acute kidney injury on outcome in elderly patients with acute coronary syndrome undergoing percutaneous coronary intervention. European Heart Journal: Acute Cardiovascular Care. 2020. (in press)

[37] Charytan D, Mauri L, Agarwal A, Servoss S, Scirica B, Kuntz, $\mathrm{RE}$. The use of invasive cardiac procedures after acute myocardial infarction in long-term dialysis patients. American Heart Journal. 2006; 152: 558-564.

[38] Szummer K, Lundman P, Jacobson SH, Schön S, Lindbäck J, Stenestrand U, et al. Influence of Renal Function on the Effects of Early Revascularization in Non-ST-Elevation Myocardial In- farction: data from the Swedish Web-System for En-hancement and Development of Evidence-Based Care in Heart Disease Evaluated According to Recommended Therapies (SWEDEHEART). Circulation. 2009; 120: 851-858.

[39] Holzmann MJ, Siddiqui AJ. Outcome of Percutaneous Coronary Intervention during Non-ST-Segment-Elevation Myocardial Infarction in Elderly Patients with Chronic Kidney Disease. Journal of the American Heart Association. 2020; 9: e015084.

[40] Baber U, Chandrasekhar J, Sartori S, Aquino M, Kini AS, Kapadia S, et al. Associations between Chronic Kid-ney Disease and Outcomes with Use of Prasugrel Versus Clopidogrel in Patients with Acute Coronary Syndrome Undergoing Percutaneous Coronary Intervention: a Report From the PROMETHEUS Study. JACC: Cardiovascular Interventions. 2017; 10: 2017 2025.

[41] Laine M, Lemesle G, Burtey S, Cayla G, Range G, Quaino G, et al. TicagRelor or Clopidogrel in severe or termi-nal chronic kidney patients Undergoing PERcutaneous coronary intervention for acute coronary syndrome: the TROUPER trial. American Heart Journal. 2020; 225: 19-26.

[42] Valle JA, McCoy LA, Maddox TM, Rumsfeld JS, Ho PM, Casserly IP, et al. Longitudinal Risk of Adverse Events in Patients With Acute Kidney Injury After Percutaneous Coronary Intervention: Insights From the National Cardiovascular Data Registry. Circulation: Cardiovascular Interventions. 2017; 10: $\mathrm{e} 004439$

[43] Huang HD, Alam M, Hamzeh I, Virani S, Deswal A, Aguilar D, et al. Patients with severe chronic kidney disease benefit from early revascularization after acute coronary syndrome. International Journal of Cardiology. 2013; 168: 3741-3746.

[44] Bangalore S, Maron DJ, O'Brien SM, Fleg JL, Kretov EI, Briguori $\mathrm{C}$, et al. Management of Coronary Disease in Patients with Advanced Kidney Disease. New England Journal of Medicine. 2020; 382: 1608-1618.

[45] Urban P, Mehran R, Colleran R, Angiolillo DJ, Byrne RA, Capodanno D, et al. Defining High Bleeding Risk in Patients Undergoing Percutaneous Coronary Intervention. Circulation. 2019; 140: 240-261.

[46] Rymer JA, Kaltenbach LA, Doll JA, Messenger JC, Peterson ED, Wang TY. Safety of Dual-Antiplatelet Therapy after Myocardial Infarction among Patients with Chronic Kidney Disease. Journal of the American Heart Association. 2019; 8: e012236

[47] Oh YJ, Kim AJ, Ro H, Chang JH, Lee HH, Chung W, et al. Low-dose aspirin was associated with an increased risk of cardiovascular events in patients with chronic kidney disease patients and low bodyweight: results from KNOW-CKD study. Scientific Reports. 2021; 11: 6691.

[48] Sarai M, Takagi Y, Ishii J, Anno H, Virmani R, Serruys PW, et al. Corrigendum to: 2017 ESC focused update on dual antiplatelet therapy in coronary artery disease developed in collaboration with EACTS. European Heart Journal. 2018; 39: 2089.

[49] Park SH, Kim W, Park CS, Kang WY, Hwang SH, Kim W. A Comparison of Clopidogrel Responsiveness in Patients with Versus without Chronic Renal Failure. The American Journal of Cardiology. 2009; 104: 1292-1295.

[50] Baber U, Mehran R, Kirtane AJ, Gurbel PA, Christodoulidis G, Maehara A, et al. Prevalence and Impact of High Platelet Reactivity in Chronic Kidney Disease: results from the Assessment of Dual Antiplatelet Therapy with Drug-Eluting Stents registry. Circulation: Cardiovascular Interventions. 2015; 8: e001683.

[51] Collet J, Cuisset T, Rangé G, Cayla G, Elhadad S, Pouillot C, et al. Bedside Monitoring to Adjust Antiplatelet Therapy for Coronary Stenting. New England Journal of Medicine. 2012; 367: 2100-2109.

[52] Best PJ, Steinhubl SR, Berger PB, Dasgupta A, Brennan DM, 
Szczech LA, et al. The efficacy and safety of short- and longterm dual antiplatelet therapy in patients with mild or moderate chronic kidney disease: Results from the Clopidogrel for the Reduction of Events during Observation (CREDO) Trial. American Heart Journal. 2008; 155: 687-693.

[53] Dasgupta A, Steinhubl SR, Bhatt DL, Berger PB, Shao M, Mak K, et al. Clinical Outcomes of Patients with Dia-betic Nephropathy Randomized to Clopidogrel Plus Aspirin Versus Aspirin alone (a post hoc Analysis of the Clopidogrel for High Atherothrombotic Risk and Ischemic Stabilization, Management, and Avoidance [CHARISMA] Trial). The American Journal of Cardiology. 2009; 103: 1359-1363.

[54] Palmer SC, Di Micco L, Razavian M, Craig JC, Perkovic V, Pellegrini F, et al. Effects of Antiplatelet Therapy on Mortality and Cardiovascular and Bleeding Outcomes in Persons with Chronic Kidney Disease: a systematic review and meta-analysis. Annals of Internal Medicine. 2012; 156: 445-459.

[55] Deharo P, Pankert M, Quilici J, Bonnet G, Bassez C, Verdier V, et al. Chronic kidney disease has a significant im-pact on platelet inhibition of new P2Y12 inhibitors. International Journal of Cardiology. 2015; 184: 428-430.

[56] Jeong KH, Cho JH, Woo JS, Kim JB, Kim W, Lee TW, et al. Platelet Reactivity after Receiving Clopidogrel Compared with Ticagrelor in Patients with Kidney Failure Treated with Hemodialysis: a Randomized Crossover Study. American Journal of Kidney Diseases. 2015; 65: 916-924.

[57] Barbieri L, Pergolini P, Verdoia M, Rolla R, Nardin M, Marino P, et al. Platelet reactivity in patients with impaired renal function receiving dual antiplatelet therapy with clopidogrel or ticagrelor. Vascular Pharmacology. 2016; 79: 11-15.

[58] Wang H, Qi J, Li Y, Tang Y, Li C, Li J, et al. Pharmacodynamics and pharmacokinetics of ticagrelor vs. clopidogrel in patients with acute coronary syndromes and chronic kidney disease. British Journal of Clinical Pharmacology. 2018; 84: 8896.

[59] Wiviott SD, Braunwald E, McCabe CH, Montalescot G, Ruzyllo $\mathrm{W}$, Gottlieb S, et al. Prasugrel versus Clopidogrel in Patients with Acute Coronary Syndromes. New England Journal of Medicine. 2007; 357: 2001-2015.

[60] James S, Budaj A, Aylward P, Buck KK, Cannon CP, Cornel $\mathrm{JH}$, et al. Ticagrelor Versus Clopidogrel in Acute Coronary Syndromes in Relation to Renal Function: results from the Platelet Inhibition and Patient Outcomes (PLATO) trial. Cir-culation. 2010; 122: 1056-1067.

[61] De Filippo O, D’Ascenzo F, Raposeiras-Roubin S, Abu-Assi E, Peyracchia M, Bocchino PP, et al. P2Y12 inhibi-tors in acute coronary syndrome patients with renal dysfunction: an analysis from the RENAMI and BleeMACS projects. Europe-an Heart Journal-Cardiovascular Pharmacotherapy. 2020; 6: 31-42.

[62] Ibanez B, James S, Agewall S, Antunes MJ, Bucciarelli-Ducci C, Bueno H, et al. 2017 ESC Guidelines for the management of acute myocardial infarction in patients presenting with STsegment elevation: The Task Force for the management of acute myocardial infarction in patients presenting with ST-segment elevation of the European Society of Cardiology (ESC). European Heart Journal. 2018; 39: 119-177.

[63] Anderson JR, Riding D. Glycoprotein IIb/IIIa Inhibitors in Patients with Renal Insufficiency Undergoing Percutaneous Coronary Intervention. Cardiology in Review. 2008; 16: 213-218.

[64] Bhatt DL, Stone GW, Mahaffey KW, Gibson CM, Steg PG, Hamm CW, et al. Effect of Platelet Inhibition with Cangrelor during PCI on Ischemic Events. New England Journal of Medicine. 2013; 368: 1303-1313.

[65] Akers WS, Oh JJ, Oestreich JH, Ferraris S, Wethington M, Steinhubl SR. Pharmacokinetics and Pharmacodynamics of a Bolus and Infusion of Cangrelor: a Direct, Parenteral P2Y12 Receptor Antagonist. The Journal of Clinical Pharmacology. 2010; 50: 27-35.

[66] O’Gara PT, Kushner FG, Ascheim DD, Casey DE, Chung MK, de Lemos JA, et al. 2013 ACCF/AHA Guideline for the Management of ST-Elevation Myocardial Infarction: a report of the American College of Cardiology Foundation/American Heart Association Task Force on Practice Guidelines. Journal of the American College of Cardiology. 2013; 61: e78-e140.

[67] Muneer K, Nair A. Angiotensin-converting enzyme inhibitors and receptor blockers in heart failure and chronic kidney disease - Demystifying controversies. Indian Heart Journal. 2017; 69: 371-374.

[68] Bainey KR, Armstrong PW, Fonarow GC, Cannon CP, Hernandez AF, Peterson ED, et al. Use of Renin-Angiotensin System Blockers in Acute Coronary Syndromes: findings from Get With the Guidelines-Coronary Artery Disease Program. Circulation. 2014; 7: 227-235.

[69] Wetmore JB, Tang F, Sharma A, Jones PG, Spertus JA. The association of chronic kidney disease with the use of reninangiotensin system inhibitors after acute myocardial infarction. American Heart Journal. 2015; 170: 735-743.

[70] Berger AK, Duval S, Krumholz HM. Aspirin, beta-blocker, and angiotensin-converting enzyme inhibitor therapy in pa-tients with end-stage renal disease and an acute myocardial infarction. Journal of the American College of Cardiology. 2003; 42: $201-$ 208.

[71] Evans M, Carrero J, Szummer K, Åkerblom A, Edfors R, Spaak $\mathrm{J}$, et al. Angiotensin-Converting Enzyme Inhibi-tors and Angiotensin Receptor Blockers in Myocardial Infarction Patients with Renal Dysfunction. Journal of the American Col-lege of Cardiology. 2016; 67: 1687-1697.

[72] Pfeffer MA, Claggett B, Lewis EF, Granger CB, Køber L, Maggioni AP, et al. Angiotensin Receptor-Neprilysin Inhibition in Acute Myocardial Infarction. New England Journal of Medicine. 2021; 385: 1845-1855.

[73] Perkovic V, Jardine MJ, Neal B, Bompoint S, Heerspink HJL, Charytan DM, et al. Canagliflozin and Renal Out-comes in Type 2 Diabetes and Nephropathy. New England Journal of Medicine. 2019; 380: 2295-2306.

[74] Heerspink HJL, Stefánsson BV, Correa-Rotter R, Chertow GM, Greene T, Hou FF, et al. Dapagliflozin in Pa-tients with Chronic Kidney Disease. New England Journal of Medicine. 2020; 383: 1436-1446. 